\title{
Para quem produzimos? Produção acadêmico-científica sobre o Direito e decisão judicial sob uma observação sistêmica
}

\author{
For whom do we produce? Academic-scientific production about the Law \\ and judicial decision under a systemic observation
}

\section{Para quién produzimos? Producción académico-científica sobre el Derecho y decisión judicial bajo una observación sistémica}

http://dx.doi.org/10.221713/2358-2332.2016.v14.1491 ${ }^{1}$

Giselle Marie Krepsky, doutora em Direito Público pela Universidade do Vale do Rio dos Sinos (Unisinos), professora da Fundação Universidade Regional de Blumenau (Furb), Blumenau, SC, Brasil. E-mail: gkepsky@furb.br.

\section{Resumo}

Este artigo apresenta uma observação dos Sistemas do Direito e da Ciência a partir da relação entre o que é comunicado cientificamente sobre o Direito e o que é julgado pelo Tribunal de Justiça de Santa Catarina. O objetivo foi identificar se há correlação temática entre o que se produz nos programas de doutorado em Direito no Brasil e o que se julga no tribunal a fim de verificar a capacidade de ressonância da academia na dogmática. A partir da teoria sistêmica de Niklas Luhmann e releituras contemporâneas, a pesquisa conclui que há alta variação temática da produção acadêmico-científica e alta repetição dos julgados possibilitando a mera reprodução do Sistema da Ciência. Logo, a produção acadêmico-científica sobre o Direito é pouco capaz de interferir nas decisões judiciais.

Palavras-chave: Produção Acadêmico-Científica. Direito e Ciência. Programas de Doutorado. Dogmática.

\begin{abstract}
This article presents an observation of the Law and Science Systems based on the relationship between what is scientifically communicated about Law and what is judged by the Court of Justice of Santa Catarina. The objective was to identify if there is a thematic correlation between what the Doctoral Programs in Law in Brazil communicate and what is judged in the court in order to verify the capacity of resonance of the academy in the dogmatics. From the systemic theory of Niklas Luhmann and contemporary reinterpretations, the conclusion reached is that there is a high thematic variation of the academic-scientific production and high repetition of the judgments allowing the mere reproduction of the Science System. Therefore,
\end{abstract}

\footnotetext{
${ }^{1}$ Como citar: ABNT NBR 6023:2002 e incluir o DOI.
} 
Krepsky / Para quem produzimos? Produção acadêmico-científica sobre o Direito e decisão judicial sob uma observação sistêmica

the academic-scientific production about Law is little capable of interference in judicial decisions.

Keywords: Academic-Scientific Production. Law and Science. Doctoral Programs. Dogmatics.

\section{Resumen}

Este artículo presenta una observación de los Sistemas del Derecho y de la Ciencia a partir de la relación entre lo que es comunicado científicamente sobre el Derecho y lo que es juzgado por el Tribunal de Justicia de Santa Catarina. El objetivo fue identificar si hay correlación temática entre lo que comunican los Programas de Doctorado en Derecho en Brasil y lo que se juzga en el tribunal a fin de verificar la capacidad de resonancia de la academia en la dogmática. A partir de la teoría sistémica de Niklas Luhmann y las relecturas contemporáneas, la investigación concluye que hay alta variación temática de la producción académico-científica y alta repetición de los juzgados, posibilitando la mera reproducción del Sistema de la Ciencia. Por lo tanto, la producción académico-científica sobre el Derecho es poco capaz de interferir en las decisiones judiciales.

Palavras clave: Producción Académico-Científica. Derecho y Ciencia. Programas de Doctorado. Dogmática.

\section{INTRODUÇÃO}

As expectativas da sociedade se alteram rapidamente com o aumento cada vez mais significativo das relações sociais, tornando a totalidade social mais complexa. Dessa forma, o atendimento a essas expectativas também recai sobre o Sistema do Direito, ao qual fica incumbido da responsabilidade de satisfazê-las de forma estabilizante do ponto de vista normativo. Inovações no âmbito das decisões judiciais são exigidas, portanto, esperam-se respostas do Judiciário que satisfaçam as demandas sociais.

No contexto da complexificação social, as relações entre Direito e Ciência têm se estreitado, levando a conexões importantes para as operações de cada um destes sistemas ocorrerem. Porém, as formas de observação da ciência jurídica (produção acadêmico-científica sobre o Direito) bem como a sua aproximação com a dogmática jurídica (decisões judiciais) demonstram obstáculos estruturais para o surgimento de novas respostas aos problemas jurídicos contemporâneos.

Partindo da teoria desenvolvida por Luhmann (2010, p. 91), para quem o conceito de sistema é: "[...] uma diferença que se produz constantemente, a partir de um único tipo de operação" e que "A operação realiza o fato de reproduzir a diferença sistema/meio, na medida em que produz comunicação somente mediante comunicação", entende-se que as comunicações só têm sentido específico em cada sistema. Um sistema só existe enquanto possível a diferenciação de seu meio, portanto, não pode existir sem um ambiente. Sendo assim, os Sistemas do Direito e da Ciência, como subsistemas ${ }^{2}$ da sociedade global, possuem códigos e

\footnotetext{
${ }^{2}$ Apesar de Direito, Ciência, Educação, Economia, entre outros, serem considerados subsistemas parciais da sociedade global, durante esta pesquisa será referido a eles apenas como "sistemas".
} 
Krepsky / Para quem produzimos? Produção acadêmico-científica sobre o Direito e decisão judicial sob uma observação sistêmica

programas próprios, funções, estrutura e comunicações diferenciadas de outros sistemas como a Política, a Economia, a Educação etc.

De acordo com a teoria sistêmica de Niklas Luhmann, os Sistemas do Direito e da Ciência são autopoiéticos. Eles são abertos cognitivamente e com capacidade de aprendizagem, mas fechados operacionalmente e adstritos aos seus códigos operacionais. O código do Direito é "conforme" ou "não conforme ao Direito", "legal" ou ilegal" ou, ainda, pode ser entendido como "direito" ou "não direito". Já os programas são as normas e regulamentos com os quais se aplica o código. Como a função do Direito é estabilizar as expectativas sociais, as suas comunicações se dão por meio das decisões.

Já o Sistema da Ciência opera com o código "verdade" ou "falsidade", ou "verdadeiro" ou "não verdadeiro" e com isso ele pode, além de obter conhecimento, também construí-lo. Assim, o código com o qual produz comunicação é uma distinção entre o que pode ser considerado "verdadeiro" ou "não verdadeiro", o que permite inferir que tanto uma condição quanto outra possa ser qualificada como científica, ou seja, qualquer comunicação que seja observável com base nessa distinção. O código científico da verdade ou falsidade é direcionado especificamente para aquisição de novos conhecimentos científicos. A Ciência opera por conceitos. Eles são uma forma de condensação capaz de conferir estrutura para a comunicação científica em permanente processo de autopoiese. Para tratar de conceitos, tem que encontrar outros conceitos. (LUHMANN, 1996). No entanto, a comunicação sobre o que é ou não é verdade depende dos programas com os quais se observam os fenômenos. Sua programação são as teorias e os métodos. São as regras que o Sistema da Ciência tem à disposição para comunicar com base no código se algo pode ser considerado verdadeiro ou não.

Para Luhmann, a sociedade é, sobretudo, comunicação. Sendo assim, faz-se importante compreender como eventuais acoplamentos entre sistemas podem interferir nas comunicações do Direito e da Ciência. Nesse tocante, a produção acadêmico-científica sobre o Direito é comunicação do Sistema da Ciência, oriunda dos centros de produção científica, em especial das universidades. As comunicações do Sistema do Direito, por sua vez, são jurídicas em caráter geral e ocorrem até mesmo na periferia ou podem se originar das decisões judiciais exaradas pelos tribunais (centro duro do Sistema do Direito). Isso demonstra que, em determinados contextos, os dois podem vir a se acoplar com vistas a uma melhor operacionalização interna tendo como consequência uma possibilidade de alteração nas suas comunicações. Já as produções acadêmico-científicas sobre o Direito são observações privilegiadas das operações realizadas pelo sistema jurídico, porquanto podem observar o que o próprio Direito e sua dogmática ocultam da sua auto-observação (LUHMANN, 1996).

Logo, essa relação de comunicações pode ser resumida da seguinte forma:

\section{Quadro 1 - Produção acadêmico-científica sobre o Direito, Teoria do Direito e Dogmática Jurídica}

\begin{tabular}{|c|l|l|l|}
\hline $\begin{array}{c}\text { Sistema de } \\
\text { pertinência }\end{array}$ & \multicolumn{1}{|c|}{ Ciência } & \multicolumn{2}{c|}{ Direito } \\
\hline Elemento observável & $\begin{array}{l}\text { Produção } \\
\text { científica sobre o Direito }\end{array}$ & Teoria do Direito & Dogmática jurídica \\
\hline Tipo de observação & $\begin{array}{l}\text { Observação da auto- } \\
\text { observação }\end{array}$ & $\begin{array}{l}\text { Auto-observação do } \\
\text { Direito }\end{array}$ & $\begin{array}{l}\text { Auto-observação do } \\
\text { Direito }\end{array}$ \\
\hline
\end{tabular}


Krepsky / Para quem produzimos? Produção acadêmico-científica sobre o Direito e decisão judicial sob uma observação sistêmica

\begin{tabular}{|l|l|l|l|}
\hline Comunicação & $\begin{array}{l}\text { Teses, dissertações e artigos } \\
\text { científicos }\end{array}$ & $\begin{array}{l}\text { Decisão jurína } \\
\text { judicial ea }\end{array}$ \\
\hline
\end{tabular}

Fonte: Elaboração própria.

Isso poderia levar à possibilidade de prestação do Sistema da Ciência para a dogmática e, ainda, para uma observação do Sistema do Direito sobre a produção acadêmica, sofisticando, assim, suas operações decisórias. Mas a dificuldade é que esta interferência intersistêmica é possível apenas quando as comunicações científicas sobre o Direito podem servir de fonte para as decisões judiciais e quando encontram no Sistema do Direito correspondência interna com seus elementos. Uma limitação autopoiética que se estende a quaisquer pretensões de irritação do Sistema do Direito.

Assim, ante o crescimento da produção científica sobre o Direito, que se consolida com o aumento de cursos de pós-graduação stricto sensu nas últimas décadasi , bem como das demandas levadas ao Poder Judiciário, o problema que surge é se há relação entre o que é produzido academicamente e o que é decidido pelos tribunais. Ou seja, se há vasta produção acadêmico-científica sobre o Direito no Brasil, é possível encontrar consonância entre o que se produz academicamente e o que o Sistema do Direito auto-observa, e, portanto, comunica a partir de decisões? Afinal, há possibilidade de assimilação da comunicação científica sobre o Direito pelos tribunais? Para tanto, segue a metodologia utilizada na pesquisa do tipo qualiquantitativa e a análise dos dados a fim de responder a estes questionamentos.

\section{COMO OBSERVAR TESES E DECISÕES: METODOLOGIA DA PESQUISA}

No âmbito do Sistema do Direito, os tribunais assumem papel decisivo na comunicação. Dessa forma, delimitou-se a investigação ao âmbito das decisões judiciais do Tribunal de Justiça de Santa Catarina (TJSC), de 2013 a 2015, com foco nas ocorrências temáticas. Como o objetivo foi estabelecer a correlação entre o que se produz cientificamente e o que se decide, a amostra da produção científica sobre o Direito partiu da classificação das principais temáticas comunicadas pelos programas de pós-graduação stricto sensu em Direito (PPGD) com conceito 6 (seis) na avaliação da Coordenação de Aperfeiçoamento de Pessoal de Nível Superior (Capes) no mesmo período dos julgados ${ }^{\text {ii. }}$ Portanto, as temáticas que foram analisadas tanto das teses quanto dos julgamentos do TJSC não foram previamente estabelecidas, mas construídas a partir da observação do que fora produzido pelas organizações envolvidas na amostra (PPGD e TJSC).

\subsection{As comunicações acadêmico-científicas: teses}

Para a construção de dados da pesquisa, utilizou-se boa parte da técnica da Análise Textual Discursiva (ATD) proposta por Moraes e Galiazzi $(2006$; 2007) por meio da qual é possível extrair os sentidos de várias unidades de um texto extenso, reunindo-os em categorias ${ }^{\mathrm{iii}}$ que os identifiquem de forma mais abrangente, sem, contudo, retirar-lhes o sentido. Esta escolha metodológica ocorreu porque, a partir das teses produzidas por cada PPGD no período de 2013 a $2015^{3}$, chegou-se a um número elevado de produtos totalizando 421 teses. Destas,

\footnotetext{
3 A coleta de dados contemplou o período entre 01/01/2013 e 15/09/2015 com base nos dados fornecidos pela Plataforma Sucupira do Portal da Capes e nos sites dos Programas.
} 
Krepsky / Para quem produzimos? Produção acadêmico-científica sobre o Direito e decisão judicial sob uma observação sistêmica

foram extraídas categorias que identificaram as grandes temáticas. Para a construção das temáticas em categorias de sentido, de modo que se pudesse identificá-las por área de observação científica, foram consultadas as teses publicadas no portal da Capes (Plataforma Sucupira) a fim de coletar os respectivos títulos e palavras-chave. Essa seleção textual, que incluiu títulos e palavras-chave de todas as teses, corresponde ao "corpus de análise" que, por sua vez, representa o conjunto das informações utilizadas na pesquisa para posterior seleção e delimitação em categorias de identificação. Como asseveram Moraes e Galiazzi (2007, p. 17): "Assumindo, contudo, que todo dado torna-se informação a partir de uma teoria, podemos afirmar que 'nada é realmente dado', mas tudo é construído". Logo, além de outras vantagens desta metodologia, verifica-se estar em plena consonância com a proposta construtivista de Luhmann, posto que, ao observar os dados, o pesquisador está, sobretudo, a construí-lo.

Assim, para identificação do corpus de análise, os autores sugerem que seja feita a seleção de um conjunto que tenha capacidade de produzir resultados que sejam válidos e que representem os fenômenos investigados (MORAES; GALIAZZI, 2007). Portanto, para se chegar ao rol de temáticas, considerou-se suficiente que o corpus fosse representado pelos títulos e palavras-chave das teses.

Feita a identificação do corpus de análise, passou-se à primeira etapa da ATD, por meio da qual há a desmontagem dos textos selecionados. Nesse momento, há uma espécie de desconstrução do texto ou o que Moraes e Galiazzi (2007) chamam de "unitarização". Na prática, a "unitarização" se dá, em suma, pelas seguintes etapas: a) fragmentação do texto original e codificação de cada unidade; b) reescrita de cada unidade de forma que ela assuma um significado; c) atribuição de um nome ou título para cada unidade produzida (MORAES, 1999). Por meio dessa fragmentação em unidades menores, a pretensão é perceber os sentidos do texto em diversos limites e seus pormenores. Há, nesse aspecto, a liberdade do pesquisador para selecionar qual a medida de fragmentação que será utilizada, elaborando unidades de análise maiores ou menores (MORAES; GALIAZZI, 2007). Assim, para Moraes e Galiazzi (2007, p. 58) "[...] a unitarização é um processo de desconstrução dos textos do corpus no sentido de diferenciação e identificação de elementos unitários constituintes”.

Dependendo do corpus selecionado, podem-se escolher palavras, frases ou até mesmo parágrafos inteiros. No contexto desta pesquisa, cujo objetivo era identificar as grandes temáticas investigativas sobre o Direito por meio das teses e da sua correlação com as grandes temáticas levadas aos tribunais, a fim de identificar os limites autopoiéticos de cada sistema, foi suficiente selecionar entre duas e quatro categorias básicas dos títulos e palavras-chave de cada tese para elaborar a "unitarização"iv.

A metodologia prevê a desconstrução por meio de critérios lexicais (baseando-se no domínio das palavras e dos vocábulos); por critérios sintáticos (o recorte do corpus ocorre com base na ordem e disposição das palavras nas frases, operando no âmbito dos significantes); e, por fim, a "unitarização" pode ser feita com base em critérios semânticos (trabalhando com a análise do significado, o sentido das palavras ou textos) (MORAES; GALIAZZI, 2007).

A metodologia proposta se encontra em consonância com a perspectiva "luhmanniana" sobre o sentido. Para que haja a "coevolução" necessária entre sistemas sociais é imprescindível que se obtenham ganhos comuns que permitam operar em meio à complexidade. O sentido sempre estará formalmente referido ao problema da complexidade. A complexidade do mundo se faz presente em cada sentido, de modo que esteja disponível e acessível para as operações 
Krepsky / Para quem produzimos? Produção acadêmico-científica sobre o Direito e decisão judicial sob uma observação sistêmica

tanto de sistemas psíquicos como dos sistemas sociais. Tais operações não destroem a complexidade, mas regeneram-na por meio dos sentidos. Não há uma redução da complexidade do mundo ao se estabelecerem os sentidos. Eles se viabilizam e qualificam a partir das possibilidades de união com a exclusão de outras consideradas improváveis ou de difícil ocorrência (LUHMANN, 1998).

Como as 421 teses impuseram uma dificuldade para o processo de "unitarização", visto que não se tratavam de tema comum, mas, sobretudo, de áreas distintas do Direito, adotar a forma puramente lexical se tornou inviável, ante a complexidade e diferenciação de sentido que cada unidade representava. Embora se pudesse dispor de ferramentas tecnológicas para a contagem de frequências lexicais, facilitando a fragmentação das unidades, tal mecanismo não se mostrou qualificável, porquanto o objetivo era descobrir temáticas abrangidas pelas teses. Um exemplo básico, nessa direção, pode ser dado com a separação lexical "Estado de Direito" que, sob a forma lexical se fragmentaria em: "Estado" + "de" + "Direito". Isso destruiria o significado da unidade textual. Portanto, optou-se por realizar manualmente o processo de "unitarização" para garantir o significado, seu conteúdo em cada tese. Então, chegou-se a 632 signos ou unidades originais correspondentes à "unitarização" do corpus de análise.

Em seguida, foram reescritas as 632 unidades originais do corpus de análise de modo que, a partir de seus textos, pudessem assumir um significado mais completo, mas, ao mesmo tempo, reduzindo a quantidade de unidades originais para outras mais abrangentes. Isso porque Moraes e Galiazzi (2007, p. 74) ressaltam que há uma organização, ordenamento ou agrupamento de um conjunto de várias unidades de análise para que se possam expressar novas ideias e compreensões acerca do que se está investigando, no caso, temas recorrentes nas teses sobre o Direito. Esta reescrita se efetuou com o agrupamento das unidades originais por similaridade de conteúdo. Ou seja, as categorias temáticas foram reagrupadas em unidades de sentido diferentes por meio da criação de novas categorias mais abrangentes. Logo, cada unidade original somente pode pertencer a uma unidade de sentido. O agrupamento das 632 unidades originais resultou 49 unidades de sentido, totalizando a frequência de 907.

Estabelecidas as unidades de sentido, passou-se a categorizá-las. Como salientam Olabuenaga e Ispizua (1989), categorizar é reunir o que é comum. A categorização se realiza por meio da comparação constante entre as unidades que foram definidas no início do processo, acarretando, pois, o agrupamento de elementos de significação que sejam próximos. Então, após estabelecer a relação entre as diversas unidades de sentido da etapa anterior e a realização de seu agrupamento por conteúdo, chegou-se a 21 categorias iniciais, a 12 categorias intermediárias e ao fechamento com uma categorial final.

Com base na metodologia proposta por Moraes e Galiazzi, utilizou-se apenas os procedimentos necessários para a classificação temática desejada obedecendo aos seguintes passos: 
Krepsky / Para quem produzimos? Produção acadêmico-científica sobre o Direito e decisão judicial sob uma observação sistêmica

\section{Figura 1 - Processo ATD - Teses}

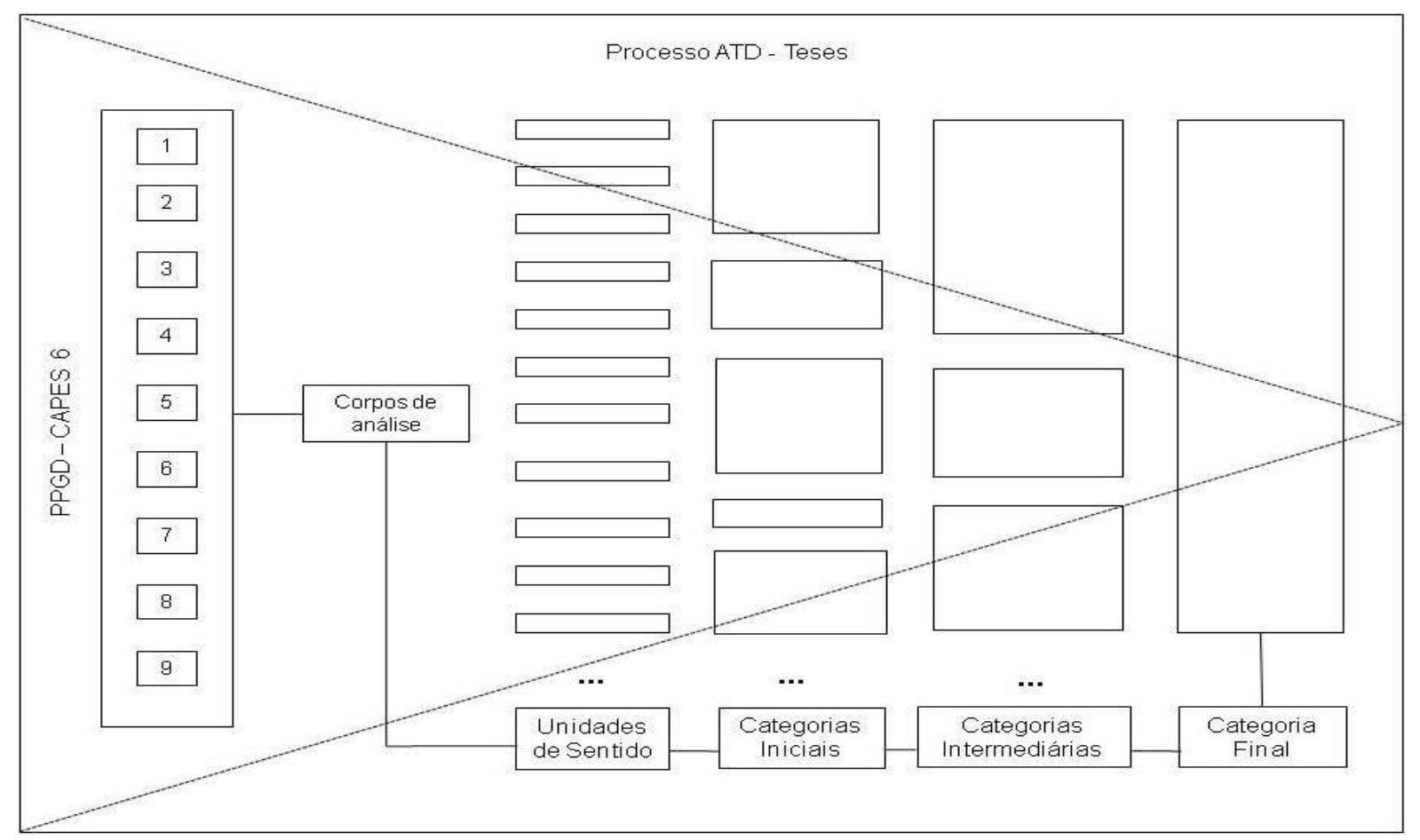

Fonte: Elaboração própria ${ }^{4}$.

O processo estabeleceu "categorias iniciais", "categorias intermediárias" e "categoria final". Esta é denominada de "Observação científica do Direito" porque se refere à totalidade das categorias, uma vez que as antecedentes indicam as comunicações oriundas do Sistema da Ciência acerca do Sistema do Direito. A categorização das temáticas das teses pode ser observada no Apêndice 1, Figura 1.

\subsection{A auto-observação do Direito: temáticas julgadas do TJSC}

Sendo o Direito um sistema pautado em comunicações, que produz e reproduz o sentido dos seus próprios elementos e suas temáticas, um dos objetivos deste trabalho foi identificar a correlação entre o que se produz cientificamente sobre o Direito e as temáticas sobre as quais o tribunal tem se manifestado.

No âmbito do Sistema do Direito, os tribunais assumem papel decisivo na comunicação. Dessa forma, delimitou-se a investigação sobre as decisões judiciais do Tribunal de Justiça de Santa Catarina (TJSC), com foco nas ocorrências temáticas dos recursos julgados. Essa seleção se deu pelos seguintes motivos: a) maior amplitude temática dos julgados em comparação aos tribunais superiores e especializados; b) estabelecimento de colaboração acadêmica entre a pesquisadora e o TJSC, uma vez que os dados não são disponibilizados de forma virtual pelos

\footnotetext{
4 A figura foi elaborada com base na "Figura 1: Unidades e diferentes níveis de categorização" (MORAES; GALIAZZI, 2007, p. 119) e com base na "Figura 12 - Processo da pesquisa qualitativa" (MORASTONI, 2013, p. $85)$.
} 
Krepsky / Para quem produzimos? Produção acadêmico-científica sobre o Direito e decisão judicial sob uma observação sistêmica

tribunais, de uma maneira geral, mas foram obtidos a partir de reuniões com a Secretaria Estatística das Instâncias Recursais do TJSC.

A aplicação da ATD dos julgados foi realizada com os dados fornecidos pelo TJSC no mesmo período utilizado para a análise temática da produção acadêmico-científica sobre o Direito. Estes dados foram fornecidos pela Diretoria de Tecnologia e Informação do Tribunal. O TJSC realiza um mapeamento por categorias principais que representam as temáticas dos recursos, tanto no ingresso quanto no julgamento.

As tabelas fornecidas ${ }^{\mathrm{V}}$ apresentaram os recursos ingressantes e julgamentos realizados no período, de acordo com as recomendações de classificação processual unificada do Conselho Nacional de Justiça (2006, 2007). Foram mapeados 174.109 recursos. Destes, 935 não foram cadastrados por assunto, então o universo pesquisado foi de 173.174. Apenas os chamados "processos principais" constaram nas tabelas fornecidas pelo TJSC, à exceção dos embargos infringentes, que são incidentes, mas foram cadastrados como principais.

Com os dados fornecidos pelo TJSC, foram construídas tabelas específicas para a aplicação da ATD, utilizando apenas os recursos julgados e não os protocolados. Então, das classes processuais fornecidas, selecionaram-se, para verificação das demandas por temáticas, apenas os recursos que não indicavam discussões meramente formais, procedimentais, processuais ou temas indiretos. Das 15 classes processuais selecionadas, encontraram-se 863 unidades temáticas para o corpus de análise com frequências que variaram de 11.788 a 1.

Para o estabelecimento das unidades de sentido e categorias foram selecionadas apenas as unidades com ocorrência igual ou superior a 10. Totalizando, assim, 376 unidades do corpus, representando 104.448 recursos. Todavia, foram extraídas da amostra 16 unidades, que não puderam ser classificadas. Ao final, a amostra analisada foi de 360 unidades, totalizando 102.375 recursos julgados.

$\mathrm{Na}$ próxima etapa, foi realizada a reescrita das unidades de forma similar às já estabelecidas no momento da elaboração dos signos temáticos das teses. Ou seja, estabeleceram-se categorias para as temáticas dos julgados que pudessem ser comparadas com as das teses. Obtiveram-se, então, 25 unidades de sentido e, em seguida, passou-se à categorização.

Depois de estabelecer a relação entre as diversas unidades de sentido da etapa anterior e a realização de seu agrupamento por conteúdo - 13 (treze) categorias iniciais e 7 (sete) categorias intermediárias - concluiu-se com uma categoria final, chamada "Auto-observação do Direito". Esta categoria final refere-se à representação da totalidade das categorias inerentes ao quadro temático de decisões do TJSC, externalizando, assim, a sua produção dogmática. A categorização das temáticas das teses pode ser observada no Apêndice 1, na Figura 2.

\section{SOBRE O QUE SE PRODUZ: A OBSERVAÇÃO CIENTÍFICA SOBRE O DIREITO}

Após a aplicação metodológica da ATD, foi possível chegar a uma observação qualiquantitativa acerca das temáticas sobre as quais os pesquisadores, por meio dos PPGD, têm se debruçado. Foram catalogadas 12 (doze) categorias intermediárias ${ }^{\mathrm{vi}}$ com os respectivos percentuais temáticos: a) Formas de compreensão do Direito (11,7\%); Operacionalização do Direito e acesso à ustiça $(21,98 \%)$; c) Relações do trabalho em empresa $(9,4 \%)$; d) Relações privadas (9\%); e) Direito e meio ambiente (4\%); f) Direito e Política $(27,1 \%)$; g) Educação e 
Krepsky / Para quem produzimos? Produção acadêmico-científica sobre o Direito e decisão judicial sob uma observação sistêmica

profissão $(2,2 \%)$; h) Inovação e tecnologia $(2,8 \%)$; i) Direito e culturas $(4,2 \%)$; j) Relações Internacionais $(3,2 \%)$; k) Direitos humanos e fundamentais $(3,6 \%)$; 1) Relações familiares e sucessões $(1 \%)$. As temáticas por categorias intermediárias podem ser melhor visualizadas por meio do Gráfico 1.

\section{Gráfico 1 - Categorias intermediárias das teses (temáticas em percentuais)}

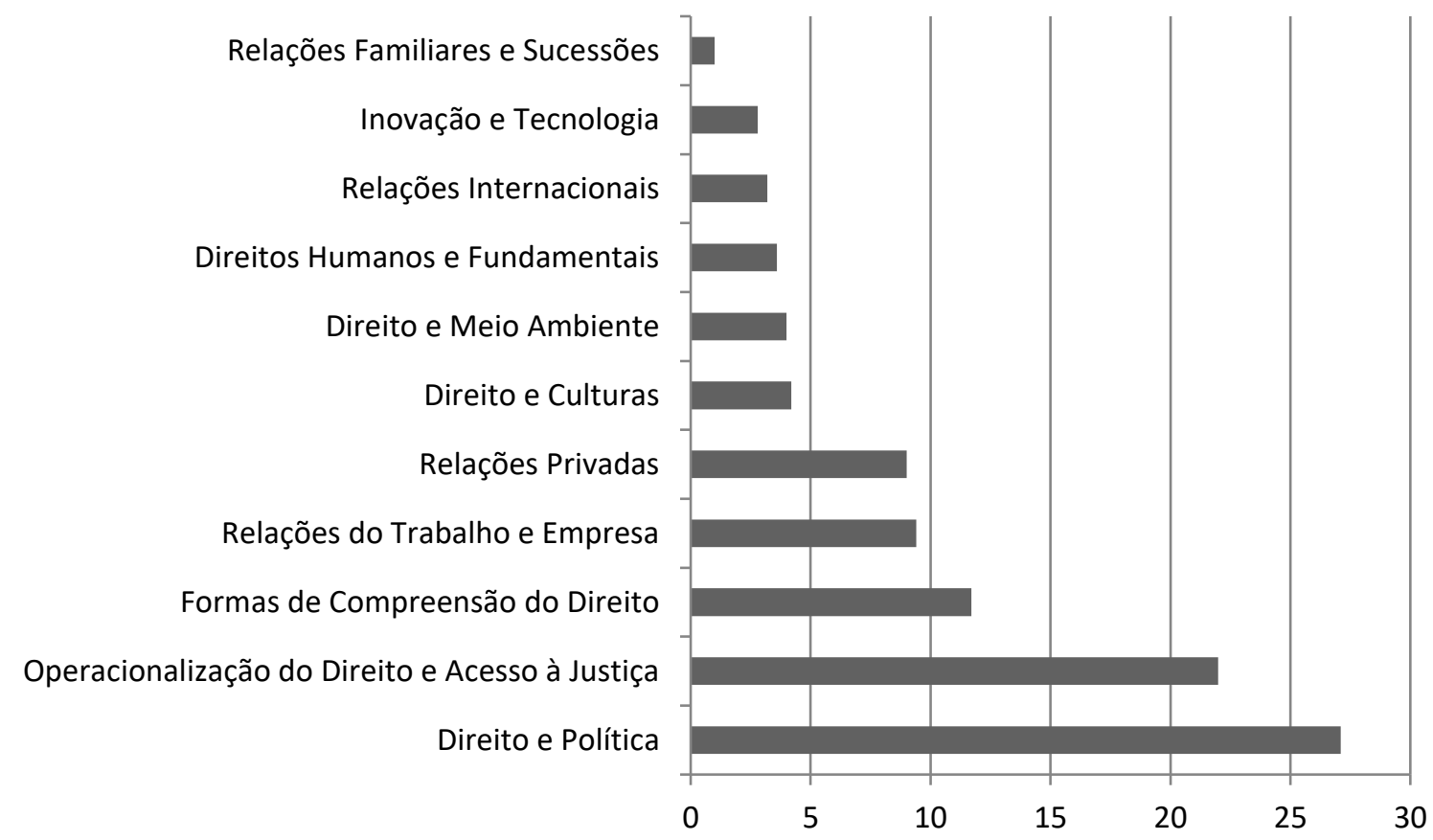

Fonte: Elaboração própria.

Do mapeamento das temáticas selecionadas para investigação no Sistema da Ciência e comunicadas por meio das teses, dentre as 12 principais categorias intermediárias verifica-se uma maior ocorrência daquelas que tratam das questões entre o Direito e Política. Em seguida, são mais incidentes as questões sobre a própria operacionalização do Direito e o acesso à Justiça. Isto é, são as mais ligadas à forma como o Direito decide e efetiva o seu acesso. Isso demonstra uma maior observação científica da própria recursividade do sistema jurídico. Assim, essas temáticas totalizam 48,9\% do que se comunica cientificamente sobre o Direito.

Com ocorrência correspondente a 11,7\% das temáticas se encontra a categoria "formas de compreensão do Direito", que é baseada preponderantemente na prestação de outras áreas do conhecimento para a observação do sistema jurídico. Pode-se considerar um resultado bastante expressivo em relação às demais categorias intermediárias. Nessa categoria, privilegiam-se questões mais teóricas e abstratas deslocando o foco para o campo operacional da própria observação científica sobre as decisões do Direito. Portanto, estão mais afetas à própria recursividade do Sistema da Ciência, com o aprimoramento de métodos e teorias para o uso em outras construções científicas sobre o Direito.

Ressalta-se que as três temáticas recorrentes tendem a privilegiar mais os próprios programas do Sistema da Ciência à operacionalização do Direito e suas inter-relações com a Política. Essas computam mais da metade da produção científica, totalizando 60,6\%. 
Krepsky / Para quem produzimos? Produção acadêmico-científica sobre o Direito e decisão judicial sob uma observação sistêmica

Constata-se ainda que temáticas relevantes relacionadas à complexidade social do século XXI como, por exemplo, o meio ambiente, a inovação tecnológica, a diversidade cultural e o mundo do trabalho atingem apenas $20 \%$ (vinte por cento) da produção científica sobre o Direito. Apesar de o Sistema da Ciência ser relativamente mais aberto aos desafios cognitivos, tais temáticas na área do Direito não sobressaem. Todavia, é preciso observar se as comunicações científicas operam nessa direção pela influência das próprias temáticas voltadas às decisões judiciais ou se as escolhas representam apenas a própria autorreprodução da Ciência, que escolhe seus programas de maneira recursiva e sem maiores interferências intersistêmicas advindas do Direito.

\section{SOBRE O QUE SE JULGA: A AUTO-OBSERVAÇÃO DO DIREITO}

Após a aplicação metodológica da ATD, foi possível desenvolver a observação qualiquantitativa de forma que ficaram evidenciadas as temáticas sobre as quais o TJSC tem decidido no mesmo período das produções científicas. Então, foram agrupadas as categorias iniciais em sete categorias intermediárias ${ }^{\mathrm{vii}}$ com os respectivos percentuais temáticos: a) Relações privadas $(52,3 \%)$; b) Direito e Política $(36,6 \%)$; c) Relações do trabalho e da empresa $(4,3 \%)^{5}$; d) Operacionalização do Direito ${ }^{6}(3,8 \%)$; e) Relações familiares e sucessões (2,5\%); f) Educação e profissão $(0,4 \%)$; g) Direito e meio ambiente $(0,1 \%)$. As categorias intermediárias das temáticas dos julgados podem ser visualizadas no Gráfico 2.

\section{Gráfico 2 - Categorias intermediárias dos julgados (temáticas em percentuais)}

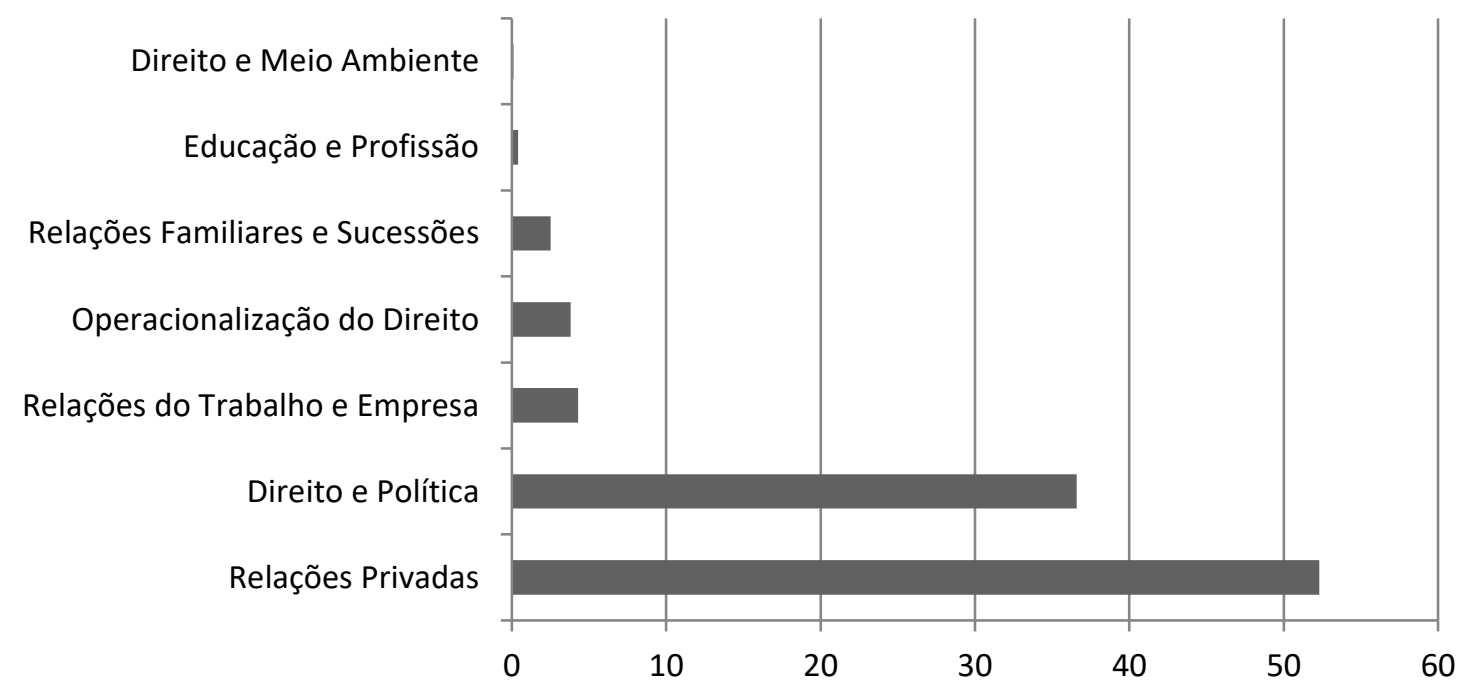

Fonte: Elaboração própria.

\footnotetext{
${ }^{5}$ Deve-se ressaltar que "Trabalho e Empresa" é categoria atípica para a amostra utilizada, uma vez que não se trata de foro privilegiado para a discussão deste tema. Todavia, foi incluída na observação temática, porque contabilizou, ainda assim, um valor significante.

${ }^{6}$ Considera-se esse percentual elevado, haja vista que foram retiradas do corpus de análise as categorias meramente processuais ou procedimentais.
} 
Krepsky / Para quem produzimos? Produção acadêmico-científica sobre o Direito e decisão judicial sob uma observação sistêmica

O que se pode observar do mapeamento dos julgados do TJSC no período e que traduz a auto-observação do Direito neste locus de decisão é que, das sete categorias intermediárias, a de maior ocorrência diz respeito a Relações Privadas (52,3\%), abrangendo mais da metade dos recursos levados a julgamento. Em seguida, e com percentual ainda maior do que se verificou nas teses, estão as questões entre Direito e Política (36,6\%), aqui também tomada como Sistema. Essas duas categorias totalizam $88,9 \%$ das temáticas julgadas. Uma maioria esmagadora em detrimento de outras temáticas.

A categoria Direito e Meio Ambiente integra apenas 0,1\% das ações no segundo grau recursal de Santa Catarina. Apenas 57 dos 102.375 recursos julgados tratavam sobre Direito e Meio Ambiente, Direito Urbanístico e Território Urbano ${ }^{7}$.

Verificando-se a correlação temática entre o que se produz cientificamente sobre o Direito e o que se julga, fica evidente que os grandes temas ou litígios levados ao tribunal se concentram de forma avassaladora em relações tipicamente privadas. Dos 102.375 recursos tomados para análise, 19.162 tratam especificamente de contratos e 14.585 de pagamentos e títulos de crédito. Ou seja, estas duas áreas específicas tomam sozinhas 32,96\% das questões levadas para julgamento de segundo grau no estado.

O outro tema bastante frequente está relacionado à criminalidade, com 16.569 recursos, totalizando $16,18 \%$ da totalidade deles.

\section{DOGMÁTICA E ACADEMIA: RELAÇÕES TEMÁTICAS}

A classificação das temáticas foi realizada com base nos conceitos operacionais das categorias intermediárias, construídas para a observação temática das teses a fim de possibilitar o cruzamento de dados entre elas e os julgados. Ainda que as categorias possam coincidir em ambas as descrições, sabe-se que qualquer auto-observação do Direito será sob a perspectiva dogmática, muito diferente da observação científica de tais temas. Logo, as categorias podem ser as mesmas, mas sua observação se dá em sistemas diferentes.

A partir da verificação temática, tanto das teses quanto dos julgados, pode-se inferir que o campo de produção científica sobre o Direito é amplo. Sobressalta a extensão temática com a qual o objeto "Direito" é explorado a partir da Ciência. Por outro lado, a auto-observação e dogmática (decisões judiciais), evidencia comunicações mais restritas.

Apresenta-se, então, o cruzamento das temáticas feito a partir das unidades de sentido, conforme o Apêndice 1, Figura 3. Do ponto de vista quantitativo, das 50 unidades de sentido estabelecidas tanto para as teses quanto para as decisões, apenas 24 coincidem $^{8}$, ou seja, estão contempladas tanto na auto-observação do Direito quanto na sua observação científica. A diversidade temática da pesquisa científica se destaca nas 25 unidades que não são encontradas nos julgados. Portanto, são observações que extrapolam a auto-observação do Direito, já que estas são restringidas por seus próprios limites estruturais. Uma evidência plausível na medida em que somente pequena parcela das demandas conflituais da sociedade alcança o centro do

\footnotetext{
${ }^{7}$ Sabe-se que, embora a temática não seja atípica para julgamentos dos Tribunais de Justiça, boa parte dos problemas inerentes ao "meio ambiente" tramitam na Justiça Federal relativizando a precariedade dos julgados.

${ }^{8}$ Sabe-se que alterando a amostra seria possível identificar maior ou menor compatibilidade temática a partir de outros Tribunais que foram excluídos da observação como os Tribunais Superiores, a Justiça Especial e a Justiça Federal da Justiça Comum.
} 
Krepsky / Para quem produzimos? Produção acadêmico-científica sobre o Direito e decisão judicial sob uma observação sistêmica

Sistema do Direito. Como alerta Luhmann, em pleno processo de "complexificação" e aceleração das mudanças estruturais há uma repercussão direta sobre as expectativas sociais sobre o Direito e, de fato, sobre vários âmbitos da sociedade. Uma das queixas advindas destas demandas, como já se sabe, recai sobre os tribunais e sua atuação que, atualmente, encontramse entre as temáticas investigativas jurídicas e sociológicas (LUHMANN, 2005).

Por outro lado, as 24 unidades em que houve coincidência de temáticas fazem relembrar as orientações no que se refere aos enlaces necessários para que se possam realizar descrições. Para Luhmann (2005, p. 568, tradução nossa), “[...] nenhum modo de descrição pode evitar o enlace com o sistema”. É claro que o sistema jurídico é suscetível de descrições internas e externas e que tanto autodescrições como heterodescrições são possíveis. Mas uma descrição externa (científica) do Sistema do Direito só será adequada ao seu objeto quando descreve o Direito como um sistema com conteúdo teórico que por sua vez se descreve a si mesmo.

Para a compreensão desta dinâmica, é importante trazer os conceitos de "redundância" e "variação" para a teoria sistêmica. A "redundância" permite que em se conhecendo um elemento do sistema se possa encontrar certo conhecimento sobre os outros elementos. Os elementos seguem mais visivelmente enlaçados, de modo que há uma redução do fator surpresa no que se refere à informação dos demais elementos. Há uma semelhança entre os elementos entre si, fazendo crescer a redundância do sistema. De acordo com Corsi, Esposito e Baraldi (1996, p. 136), uma mensagem que comunique algo que já é conhecido é altamente redundante. Cada comunicação produz redundância na medida em que, quando A dá uma informação a $\mathrm{B}$, um $\mathrm{C}$ qualquer pode se dirigir tanto a $\mathrm{A}$ quanto a $\mathrm{B}$ para obter a informação. A redundância voltada à segurança e estabilidade da comunicação e à capacidade de enlace no sistema permite que se poupe tempo para comunicar (SOTO DEL ÁNGEL, 2008). Isso também ocorre no Sistema do Direito, que, sendo orientado para a redundância (repetição), possibilita que seja possível partir de um caso concreto e encontrar para este caso o direito correspondente (subsunção). Como a redundância é voltada para a segurança e a permanência das operações que diferenciam as informações, como, por exemplo, a que distingue "alienação parental" do que não é alienação parental, a sua capacidade de relação com a novidade no sistema é limitada. A sua função é exatamente manter estável e confiável a comunicação de que alienação parental é isto e não aquilo, facilitando as operações seguintes. Isto serve tanto para o Sistema da Ciência quanto para o do Direito.

Já a "variação" deve designar a diversidade de acontecimentos que um sistema reproduz internamente. Com o aumento da "variação", um sistema pode aumentar a sua abertura com o entorno e por isso está relacionado com o grau de complexidade suportável e posteriormente reduzido internamente (LUHMANN, 1996). Tal conceito está relacionado com a capacidade de abertura e aprendizagem dos sistemas.

Ora, o fato de que haja mais acontecimentos que tumultuem o sistema e aumentem sua abertura para o meio em nada afetará o fechamento operacional deste. Mas eles são capazes de modificar as possibilidades estruturais e os acoplamentos operativos. Isso permite que possa ter tanto mais acontecimentos no entorno quanto no sistema. E quanto maior for a turbulência no entorno, o que também pode ser tido como irritações, mais o sistema fará coincidir seus próprios acontecimentos com o entorno e maior será a variação (LUHMANN, 1996).

Então, volta-se a questão, quanto maior a variação temática produzida e comunicada pela Ciência no que se refere ao Direito, maior seria a chance de irritação do Sistema do Direito, 
Krepsky / Para quem produzimos? Produção acadêmico-científica sobre o Direito e decisão judicial sob uma observação sistêmica

colocando-o em abertura e reformulação estrutural, refletindo em suas decisões. No entanto, Corsi, Esposito e Baraldi (1996) salientam que um excesso de redundância na comunicação científica sobre o Direito, ou seja, uma repetição e reprodução exacerbada de comunicação científico-jurídica reflete numa menor possibilidade de ressonância e consequentemente destina a produção e a publicação científica sobre o Direito apenas para a reprodução do Sistema da Ciência. Logo, a variação é salutar, porque corresponde a uma multiplicidade de elementos de um sistema, mas também representa a improbabilidade de se prever cada um dos conhecimentos ou elementos a partir dos outros, aumentando o fator surpresa e diminuindo a capacidade de enlace das comunicações.

Luhmann (1996) explica que, de alguma forma, o benefício que se obtém com esta forma de equilíbrio entre a "redundância" e a "variação" e, sobretudo, a partir do que já é sabido e possui enlaces no sistema, é o de que a consistência da memória não é excedida totalmente. Até porque, se o sistema fosse bombardeado constantemente com coisas estranhas o tempo todo, isso se tornaria trivial tanto quanto uma repetição interminável de uma afirmação já conhecida. Então, a constrição torna possível manter o foco reativando e reafirma o já sabido, mas agora aplicado de outra forma ou em outro contexto. No mesmo passo, colocam as possibilidades dos erros científicos e a construção de teorias que intencionam observar o mundo e sua consequente necessidade de revisão e correção.

Na sequência do cruzamento de dados, vale destacar que, mesmo com a coincidência de 24 unidades temáticas nos dois sistemas, nove delas, embora tratassem sobre fenômenos semelhantes, foram observadas de forma muito discrepante. Ressalta-se, por exemplo, que o tema "contratos" compreende $18,71 \%$ de toda a auto-observação temática do TJSC no período, mas apenas 2,43\% da observação acadêmico-científica. Logo, é possível visualizar muito mais dissonância e variação disponibilizada pela Ciência do que a abertura cognitiva do Direito possa suportar. Assim, parece prejudicado o equilíbrio necessário entre "variação" e "redundância" para uma efetiva irritação na dogmática.

Os contratos se encontram na periferia do Sistema do Direito, assim como o que se tem por Direito Privado. Na periferia não se tem a obrigação de decidir, há uma maior abertura cognitiva e maior contato com o entorno. Se apenas uma pequena margem de conflitos é levada ao centro do Sistema do Direito para decisão, supõe-se que eles sejam ainda em maior quantidade nesta área. Pode-se afirmar que as questões contratuais e privadas de um modo geral compreendem o maior índice de invocação do centro decisório do Sistema do Direito. Isso está imbricado com o aumento de "policontextos" que exigem rápidas transformações de leitura da Economia pelo Direito. Para Tepedino (2012, p. 19) “comunicação e o pluralismo falam por si. É inegável a rapidez e a eficiência das comunicações, interferindo diretamente nos modelos e disciplinas contratuais".

Se esse valor for somado a outros que, pode-se dizer, estão diretamente vinculados, como: "consumo e comércio" com 10,29 \% e "pagamentos e títulos de crédito" com 14,24\%, esta temática ocupará 43,24\% de todas as demandas do TJSC. Ou seja, quase metade do que se leva ao tribunal está vinculado a questões mais relativas ao Direito Privado por excelência. Porém, não se percebe preocupação do Sistema da Ciência em descrever tais temáticas. Se isto se realiza, é em percentual de pouca expressividade. Verifica-se que a temática "pagamentos e títulos de crédito" é a única que não comportou nenhuma observação acadêmico-científica. 
Krepsky / Para quem produzimos? Produção acadêmico-científica sobre o Direito e decisão judicial sob uma observação sistêmica

Sendo que "contratos" e "consumo e comércio" totalizaram apenas 4,97\% da produção científica.

Na seara do acoplamento entre Direito e Economia, enquanto temática observada, podese acrescentar "responsabilidade e indenizações" cuja auto-observação do Direito ocorre em $7 \%$ das demandas, mas a sua observação científica transcorre apenas em 1,1\% das produções. Portanto, ao final da soma destas unidades de sentido mais semelhantes de auto-observação do Direito, verifica-se que mais da metade das demandas $(50,24 \%)$ se concentram em situações decisórias que envolvem Direito e Economia, o que está em plena consonância com o percentual descrito na categoria intermediária dos julgados do TJSC - Relações Privadas - a que acabou totalizando 52,3\% das demandas contra apenas $9 \%$ da categorização temática das teses na mesma área.

A unidade de sentido "violência, criminalidade e segurança" atingiu 16,18\%. Assim, esta única unidade, sem qualquer outro agrupamento, colocou-se como segunda maior demanda levada ao tribunal para decisão. Apesar de sua ocorrência ser 295,59\% maior do que a observação acadêmica a respeito, que totalizou 4,09\%, não se pode desprezar o esforço acadêmico-científico que se despende para esse tema, uma vez que ocupa o $7^{\circ}$ lugar entre os mais pesquisados. Porém, com relação ao alto percentual ocupado na dogmática, percebe-se que há uma carência de produção acadêmico-científica com vistas a propiciar uma prestação do Sistema da Ciência. Além disso, tal temática pode ser a que mais exija a capacidade de observação a partir do acoplamento de diversos sistemas, aumentando a percepção interdisciplinar do fenômeno. Afinal, não é preciso ir longe para observar conflitos sociais nessa seara, ou seja, no centro ou periferia do Sistema do Direito, a temática criminalidade, além de recorrente, é observada sob o prisma de várias subáreas do Sistema da Ciência.

Seguindo na ordem de maior prevalência temática encontrada nos julgados, evidenciase ainda a unidade "Saúde, Previdência, Seguridade e Assistência" com 10,52\%. São exatos $253,02 \%$ a mais do que os $2,98 \%$ que esta temática ocupa no campo de observação dos programas de pós-graduação stricto sensu. Já as questões que envolvem o "Sistema Financeiro Nacional" não ocupam um percentual muito relevante no total das temáticas julgados no TJSC, correspondendo a 4,77\%. Porém, novamente se observa uma dissonância entre a ocorrência de julgados e a observação acadêmica, posto que somente $0,77 \%$ desta temática se encontra nas teses, evidenciando uma diferença de $519,48 \%$ entre uma observação e outra.

Por fim, e ainda na observação das maiores diferenças consideradas a partir dos temas mais relevantes em ocorrência no TJSC, tem-se a unidade que trata das "relações parentais, das famílias e diversidade sexual" com 2,37\% das temáticas julgadas. Entretanto, mais uma vez a observação acadêmico-científica não tem empregado o mesmo nível de observação sobre o fenômeno, com apenas $0,77 \%$ das temáticas.

Analisando-se as diferenças a partir da maior ocorrência da produção científica e com uma enorme incongruência quantitativa, tem-se o tema "Direito e Meio Ambiente" que comporta um percentual de apenas $0,04 \%$ das temáticas dos julgados do TJSC. Isto representa um percentual de $8.175 \%$ a menos do que os 3,31\% de observação científica do Direito nessa matéria. Apenas 57 dos 102.375 dos recursos julgados tratavam sobre Direito e Meio Ambiente, Direito Urbanístico e Território Urbano. Muito embora a diferença seja muito elevada, percebese que os 3,31\% das temáticas das teses não são expressivos diante de tantas outras que possuem percentuais maiores. 
Krepsky / Para quem produzimos? Produção acadêmico-científica sobre o Direito e decisão judicial sob uma observação sistêmica

Não há como desconsiderar que, em meio à atual complexidade social, há reflexos nas condições de sobrevivência humana em meio a alterações ambientais asseveradas e cujas decisões precisam levar em consideração danos futuros, que o percentual de temáticas que observam cientificamente sobre a dogmática ambiental é pouca. Isso ganha especial relevância diante do chamado Estado Ambiental a partir do processo de "ecologização" do Direito e da Política que, acoplados, sensibilizam-se com as irritações ecológicas e exteriorizam-se por meio do compromisso intra e intergeracional da Constituição Federal brasileira (CF) estipulado no artigo 225 (ROCHA; CARVALHO, 2006). De fato, para Krepsky (2015), o que é necessário para uma estruturação paradigmática voltada para uma observação mais especializada das ocorrências ambientais é uma paulatina alteração estrutural do Direito. Esta propiciada pelas irritações, as quais poderiam ser fomentadas por uma maior variação da produção acadêmicocientífica, impulsionando uma seleção do Direito a partir da inovação produzida nos PPGD.

Percebe-se que $21,8 \%$ das teses têm se debruçado sobre a própria operacionalização do Direito e o acesso à Justiça. Se somar a esse percentual os 11,7 \% de "formas de compreensão do Direito" cujas unidades de sentido incluem: "teóricos, teorias e metodologias", "Direito e história", "Direito e linguagem", "bioética", "sujeito e subjetividade", "moral e valores", temse que 33,5\% de temáticas das teses são voltadas para operacionalização, compreensão do Direito e acesso à Justiça, caracterizando uma observação predominantemente sociológica, filosófica, entre outras.

Nessas questões de operacionalização do Direito, faz presente a preocupação com a excessiva carga dos tribunais, a duração dos processos, sua efetividade e as investigações sobre o acesso à Justiça. Afinal, acesso à Justiça é acesso aos tribunais (centro do sistema). Nesse sentido, uma questão importante colocada por Luhmann (2005) é a de se os procedimentos jurídicos são um mecanismo adequado para a solução dos conflitos. Afinal, se tudo que é levado aos tribunais está sujeito à decisão obrigatória, tornam-se "judicializáveis" apenas reduzidos segmentos temáticos. O que em boa medida advém do filtro estabelecido estruturalmente.

Se a partir das unidades de sentido podem-se tecer tais observações, vale destacar, ainda, a comparação a partir das categorias intermediárias, as quais agruparam unidades temáticas compatíveis entre si de modo a gerar novo sentido conforme explicitado anteriormente. Enquanto a auto-observação do Direito comporta 52,3\% das temáticas no âmbito das "relações privadas", apenas $9 \%$ da observação acadêmica ocorre nesta mesma categoria. Se incluir ainda neste rol a categoria inicial "relações da empresa" e "relações familiares e sucessões", embora a dicotomia entre público versus privado seja discutível ante suas atuais aproximações, 59,1\% da auto-observação contra apenas $19,4 \%$ da produção científica, o que ainda coloca a pesquisa na área privada em total descompasso com o que é julgado pelo TJSC.

Ademais, $21,83 \%$ das teses têm se debruçado sobre temas que envolvem a própria operacionalização do Direito e as formas de acesso à Justiça, enquanto o Sistema do Direito não tem encontrado maiores dificuldades, sendo pouco exigido a decidir tematicamente nesse viés, uma vez que apenas $2,25 \%$ dos julgados comportam este tema.

As temáticas das teses que tratam das "formas de compreensão do Direito" e da "operacionalização do Direito e acesso à Justiça" comportam 33,5\%. Isso demonstra que as teses estão preocupadas em como o Direito atua. Mesmo assim, as discrepâncias encontradas nos percentuais demonstram que não é fácil interferir nas decisões jurídicas ou no modus operandi do Direito por meio da produção acadêmico-científica. 
Krepsky / Para quem produzimos? Produção acadêmico-científica sobre o Direito e decisão judicial sob uma observação sistêmica

\section{CONSIDERAÇÕES FINAIS}

O foco da observação se direcionou para a qualificação temática advinda da produção acadêmico-científica sobre o Direito produzida no âmbito dos PPGD (teses) e para a sua capacidade de irritação sistêmica na dogmática jurídica. As conclusões, nos limites desta investigação, recaem sobre a dissonância temática entre a observação científica e a autoobservação do Direito. A partir da verificação empírica da produção de teses dos oito PPGD com nota seis pelo sistema de avaliação da Capes e das temáticas julgadas pelo TJSC no período compreendido entre 2013 e 2015, algumas constatações se mostraram importantes na análise da capacidade de impacto da produção acadêmico-científica sobre o Direito.

Constatou-se que o campo da investigação científica sobre o Direito é amplo. Sobressalta a extensão temática com a qual o objeto "Direito" é observado pelo Sistema da Ciência, incluídas as diversas subáreas teóricas sob as investigações se efetivam. Há uma alta "variação", muito mais do que reprodução do conhecimento por parte da observação científica quando são analisadas as temáticas em unidades distintas. Por outro lado, a auto-observação do Direito (decisões) evidencia um campo temático mais restrito. Esta situação pode ser considerada normal, tendo em vista que nem todos os problemas jurídicos são levados à decisão nos tribunais e pelo fato de que o Direito não conhece outro Direito que não seja o autoproduzido por ele. Além disso, o seu fechamento operacional restringe tal amplitude.

Ademais, verificou-se que as teses do período selecionado mostram que as temáticas mais selecionadas para investigação tratam das questões entre o Direito e a Política tomada como sistema. Em seguida, têm-se teses cuja observação científica é sobre a própria operacionalização do Direito e o acesso à Justiça, ou seja, são teses mais ligadas à forma de como o Direito decide e efetiva o seu acesso em detrimento dos próprios direitos para os quais a sociedade espera a devida tutela jurídica. Isso demonstra uma maior observação científica da própria recursividade do sistema jurídico.

A recursividade do Sistema da Ciência se mostrou presente nas teses sobre o Direito, uma vez que a categoria "formas de compreensão do Direito", que é baseada preponderantemente na prestação de outras áreas do conhecimento para a observação do sistema jurídico, ocupou a terceira maior temática. Isso também demonstra que, a partir do sistema científico, os pesquisadores têm se debruçado sobre formas de como observar o Direito, como se as programações (teorias e métodos) do Sistema da Ciência não comportassem ainda tais subsídios internamente. Isto indica que sempre se pode observar diferentemente.

Ressalta-se que entre as categorias iniciais das teses, a primeira preocupação da observação científica trata do Direito e da decisão; em segundo, das formas de compreensão do Direito; em terceiro, das relações privadas propriamente ditas; e em quarto lugar, do processo. Conclui-se que a operacionalização do Direito tem grande destaque na produção científica.

Apesar de o Sistema da Ciência ser voltado para as expectativas cognitivas, com maior abertura e aprendizagem no que se refere à produção acadêmico-científica sobre o Direito, tais observações não sobressaem. Urge refletir sobre questões que se encontram no bojo de grandes discussões internacionais e que afetam o global e o local, como Direito e Meio Ambiente que integram apenas $0,1 \%$ das ações no segundo grau recursal de Santa Catarina. Por certo, isso não pode denotar que o estado de Santa Catarina não tenha problemas ambientais a serem 
Krepsky / Para quem produzimos? Produção acadêmico-científica sobre o Direito e decisão judicial sob uma observação sistêmica

enfrentados, mas sim, que existem outros meios de solução destes problemas, seja na periferia do Sistema do Direito em outras jurisdições.

Há, evidentemente, uma quantidade enorme de repetições temáticas levadas ao judiciário e pouca variedade temática. Isso é relevante, pois, apesar de a sociedade contemporânea ser "policontextural" e dotada de alta complexidade, tais policontextos ou diversidades não parecem chegar com frequência ao centro do Sistema do Direito, podendo denotar que as grandes diferenças deste Sistema se deslocam para a sua periferia, incluindo as formas alternativas de solução de conflitos. Todavia, pode-se conjecturar que, novamente, órgãos e entidades localizadas na periferia do sistema jurídico possam realizar este filtro, bem como tais contendas possam ser bem administradas pelo sistema no primeiro grau de jurisdição.

Restou evidente que os grandes temas ou litígios levados ao tribunal se concentram de forma avassaladora em relações tipicamente privadas. Tendo na sequência uma temática socialmente relevante e com percentual elevado que é a questão da criminalidade.

Embora a produção acadêmica seja voltada para os "policontextos" do Direito, ela pode evidenciar observações sobre os fenômenos jurídicos que não interessam à dogmática ou não se incluem efetivamente no rol de demandas levadas à decisão. Mesmo nas demais unidades em que houve coincidência temática, percebeu-se que elas são observadas de forma muito diferentes. Destaca-se então a ínfima capacidade de enlace necessário para que os acoplamentos sejam bem-sucedidos.

Reforça-se, assim, a dificuldade de ressonância na dogmática jurídica advinda do Sistema da Ciência. Afinal, existem barreiras operacionais de observação e assimilação do Direito pelo que é produzido pelas academias que se acentua quando a comunicação científica não está adstrita à auto-observação (dogmática) dos poucos temas que se transformam em demandas a serem julgadas. Isso leva a cogitar que as produções acadêmico-científicas sobre o Direito que mais alcançariam potencial de ressonância nas decisões são as que mais se identifiquem com o objeto do Direito, sua dogmática, limitando, pois, o próprio campo observacional científico.

Verificou-se também uma dissonância temática que trata da esfera Pública versus Privada. Mais da metade dos julgados do TJSC tratam de "relações privadas", enquanto menos de um décimo da observação acadêmica ocorre nesta mesma área. Isto está em consonância com as áreas de concentração dos PPGD, posto que mais da metade das suas áreas de concentração se referem ao Direito Público ${ }^{9}$. Portanto, é possível perceber o direcionamento dos programas de doutorado para o estudo constitucional do Direito, fazendo sobrepor ou integrar a esfera pública com a esfera privada, conforme demonstram os números. Eis o caráter de vanguarda e constante aprendizagem do Sistema da Ciência na observação dos fenômenos jurídicos, não somente deles, uma vez que o Sistema da Ciência pode se valer da interdisciplinaridade para realizar suas operações e comunicações.

Mas se por um lado esse caráter cognitivo da produção científica do Direito lhe permite prospectar um desenvolvimento social de acordo com esta seleção teórico-prática, por outro, a possibilidade de irritação na dogmática é limitada pelo evidente descompasso temático entre o que se julga e o que se observa externamente aos olhos da Ciência. Logo, observou-se muito

\footnotetext{
${ }^{9}$ Com base nas áreas de concentração e as linhas de pesquisa dos Programas de Doutorado utilizados na pesquisa, de acordo com a Plataforma Sucupira da Capes e os sites dos PPGD.
} 
Krepsky / Para quem produzimos? Produção acadêmico-científica sobre o Direito e decisão judicial sob uma observação sistêmica

mais dissonância e variação disponibilizada pela Ciência do que a abertura cognitiva do Direito. Assim, parece prejudicado o equilíbrio necessário entre variação e redundância para uma efetiva interferência na dogmática.

Chega-se então a um impasse: como produzir conhecimento acadêmico-científico sobre o Direito que atenda aos critérios da Ciência e ao mesmo tempo ofereça prestação para o Direito se este se contenta com a própria produção dogmática? Esta questão parece se deslocar para outro foco. De acordo com Luhmann (2005), as descrições externas sobre o Direito (sejam elas de fins mais jurisprudenciais, sociológicos, filosóficos ou sob qualquer outro tipo de programa científico que se eleja e que seja dirigido para o uso do sistema jurídico) não tem o Sistema do Direito como destinatário, mas sim o Sistema da Ciência. E isso é determinante para se pensar em irritação sistêmica da Ciência na dogmática. Ou seja, se produz cientificamente para comunicar da mesma forma e para o próprio Sistema da Ciência, muito mais do que para uma efetiva alteração do Sistema do Direito, que, sendo fechado operacionalmente, apresenta limitações para decidir com base na produção científica. Enfim, os cientistas jurídicos produzem eminentemente para outros pesquisadores jurídicos, em um ciclo de constante reprodução.

Conclui-se então que, entre outros fatores, devido à autopoiese dos sistemas, a função social da pesquisa acadêmica é deveras restrita na área jurídica de modo que, paradoxalmente, as pesquisas que mais podem produzir interferências nas decisões são as que mais se aproximam das próprias temáticas que o tribunal julga, restringindo uma maior inovação nas decisões. Mas esta é apenas uma observação sobre a capacidade de interferência da produção acadêmicocientífica sobre a dogmática.

\section{Notas explicativas}

${ }^{\text {i }}$ Com base nas informações do portal da Capes e do CNPq, pode-se inferir que, de 1997 até 2010, a produção na área do Direito contempla o aumento de 895,19\% de autores; $1.263,65 \%$ de artigos completos em periódicos especializados nacionalmente; $1.491,87 \%$ de trabalhos completos publicados em anais de eventos; 956,21\% de livros; 3.572,22\% de capítulos de livros. Em 1981, eram 12 programas de mestrado e 4 de doutorado. Em 2004, eram 37 mestrados e 15 doutorados. Em 2017, estão em funcionamento no Brasil 142 cursos de pós-graduação em Direito. Destes, 99 são mestrados acadêmicos, 7 são mestrados profissionais e 36 são doutorados. Cf. Coordenação de Aperfeiçoamento de Pessoal de Nível Superior ([2016]); Conselho Nacional de Desenvolvimento Científico e Tecnológico ([2016]).

ii Os Programas de Pós-Graduação em Direito com nota 6 observados são: Pontifícia Universidade Católica de Minas Gerais (PUC-MG); Pontifícia Universidade Católica do Rio Grande do Sul (PUCRS); Universidade de Brasília (UnB); Universidade de São Paulo (USP); Universidade do Vale do Rio dos Sinos (Unisinos); Universidade Federal de Minas Gerais (UFMG); Universidade Federal de Santa Catarina (UFSC) e Universidade Federal do Paraná (UFPR). Em 2017 estes Programas continuam sendo os únicos com conceito 6 na avaliação da Capes.

${ }^{i i i} \mathrm{O}$ construtivismo que serve de base para a pesquisa estende-se, sobretudo, às questões metodológicas que sustentam a produção e a análise empírica. Sendo o conhecimento sempre uma construção de um observador e não a exata correspondência coma realidade externa, conforme Corsi, Esposito e Baraldi (1996, p. 51), destaca-se que tanto categorias quanto as subcategorias construídas para a análise sempre têm relação com o fenômeno que se está a observar e são inerentes à capacidade que o pesquisador tem para perceber e construir diferentes estruturas e classificações para melhor elucidação dos conceitos. Sendo as categorias decomposição do corpus textual originário e reconstrução de sentidos, o conjunto de categorias sempre será válido na medida em que for capaz de propiciar uma nova compreensão sobre os fenômenos pesquisados. Cf. Moraes e Galiazzi (2007). 
Krepsky / Para quem produzimos? Produção acadêmico-científica sobre o Direito e decisão judicial sob uma observação sistêmica

iv "Ao concretizar a unitarização é importante que o pesquisador esteja consciente das implicações que esse processo acarreta. Analisar significa dividir, separar. Qualquer análise decompõe um todo em partes para, a partir de então, atingir a nova compreensão do todo, mais complexa do que a inicial. Assim, a unitarização implica uma fragmentação dos textos submetidos à análise" (MORAES; GALIAZZI, 2007, p. 114-115).

${ }^{v}$ Elas contemplaram recursos dos seguintes órgãos julgadores do TJSC: Câmara Civil Especial; Câmara Especial Regional de Chapecó; Grupo de Câmaras de Direito Civil, Público e Comercial; Órgão Especial; Plantão Judiciário; $1^{\mathrm{a}}$ a $4^{\mathrm{a}}$ Câmaras de Direito Criminal; $1^{\mathrm{a}}$ a $6^{\mathrm{a}}$ Câmara de Direito Civil; $1^{\mathrm{a}}$ a $5^{\mathrm{a}}$ Câmaras de Direito Comercial; $1^{\mathrm{a}}$ a $4^{\mathrm{a}}$ Câmaras de Direito Público; $1^{\mathrm{a}}$ Vice-Presidência; Pleno e Seção Criminal.

${ }^{\mathrm{vi}}$ As 21 categorias iniciais das temáticas observadas cientificamente foram: Conflito e solução; Crime e sociedade; Culturas, coletividades e cooperação comunitária; Direito e decisão; Direito e Estado Constitucional; Direito e Filosofia; Direito e meio ambiente; Direitos humanos e fundamentais; Educação e profissão; Formas de compreensão do Direito; Inovação e tecnologia; Poder Legislativo; Política e Administração Pública; Processo; Relações da empresa; Relações de poder; Relações do trabalho; Relações familiares e sucessões; Relações Internacionais; Relações privadas; Tributação, orçamento e economia. Elas foram agrupadas de modo que foi possível estabelecer as 12 categorias intermediárias.

vii As 13 categorias iniciais das temáticas julgadas pelo TJSC foram: Acesso à Justiça; Processo; Relações do Trabalho; Relações da Empresa; Relações Privadas; Direito e Meio Ambiente; Relações e Poder; Crime e Sociedade; Direito e Estado Constitucional; Controle e Administração Pública; Tributação e Economia; Educação e Profissão; Relações Familiares e Sucessões que foram agrupadas nas sete categorias intermediárias.

\section{Referências}

CONSELHO NACIONAL DE DESENVOLVIMENTO CIENTÍFICO E TECNOLÓGICO. Indicadores de Pesquisa. Brasília, DF: Ministério da Ciência, Tecnologia, Inovações e Comunicações, [20-?]. Disponível em: 〈https://goo.gl/wBuxR1>. Acesso em: 10 ago. 2017.

CONSELHO NACIONAL DE JUSTIÇA. Resolução $\mathrm{n}^{\circ}$ 12, de 14 de fevereiro de 2006. Cria o Banco de Soluções do Poder Judiciário e dá outras providências. Diário da Justiça, Brasília, DF, 23 mar. 2006. p. 81. Disponível em: 〈https://goo.gl/uJRZg2〉. Acesso em: 12 jun. 2017.

Resolução no 46, de 18 de dezembro de 2007. Cria as Tabelas Processuais Unificadas do Poder Judiciário e dá outras providências. Diário da Justiça, Brasília, DF, 21 dez. 2007. p. 19. Disponível em: 〈https://goo.gl/Zu8XrV>. Acesso em: 12 jun. 2017.

COORDENAÇÃO DE APERFEIÇOAMENTO DE PESSOAL DE NÍVEL SUPERIOR. Plataforma Sucupira. Brasília, DF, [2016]. Disponível em:< https://sucupira.capes.gov.br/sucupira/public/consultas/coleta/trabalhoConclusao/listaTrabalh oConclusao.jsf>. Acesso em: 8 ago. 2017.

CORSI, G.; ESPOSITO, E.; BARALDI, C. Glosario sobre la teoria social de Niklas Lukan. Ciudad de México: Universidad Iberoamericana, 1996.

KREPSKY, G. M. Direito, ciência e risco ambiental: ecocomplexidade, futuro e compromisso constitucional intergeracional. In: MELO, M. P.; ROCHA, L. S. (Org.). Políticas constitucionais e sociedade: jurisdição e democracia. Curitiba: Prismas, 2015. v. 2. p. 297- 
Krepsky / Para quem produzimos? Produção acadêmico-científica sobre o Direito e decisão judicial sob uma observação sistêmica

316.

LUHMANN, N. La ciencia de la sociedad. Ciudad de México: Universidad Iberoamericana, 1996.

Sistemas sociales: lineamentos para una teoría general. México: Anthropos, 1998.

El derecho de la sociedad. Ciudad de México: Universidad Iberoamericana, 2005.

Introdução à teoria dos sistemas. 2.ed. Petrópolis: Vozes, 2010.

MORAES, R. Análise de conteúdo. Educação, Porto Alegre, XXII, n. 37, p. 7-32, mar. 1999.

MORAES, R.; GALIAZZI, M. C. Análise textual discursiva: processo reconstrutivo de múltiplas faces. Ciência e Educação, Bauru, v. 12, n. 1, p. 117-128, jan./abr. 2006. Disponível em: <>. Acesso em: 26 maio 2017.

Análise textual discursiva. Ijuí: Unijuí, 2007.

MORASTONI, E. P. O sistema de justiça e a prevenção aos riscos de desastres: a compatibilidade entre as decisões judiciais e a prioridade de ação 4 do marco de ação de Hyogo. 2013. 150 f. Dissertação (Mestrado em Desenvolvimento Regional) - Universidade Regional de Blumenau, Blumenau, 2013.

OLABUENAGA, J. I. R.; ISPIZUA, M. A. La descodificación de la vida cotidiana: métodos de investigación cualitativa. Bilbao: Universidad de Deusto,1989.

ROCHA, L. S.; CARVALHO, D. W. Policontexturalidade e direito ambiental reflexivo. Seqüîncia, Florianópolis, v. 27, n. 53, p. 20, dez. 2006.

SOTO DEL ÁNGEL, J. La autorreproducción del sistema de la ciencia en el campo académico de la comunicación en México: una reflexión a partir de Niklas Luhmann. 2008. 416 f. Tese (Doutorado em Comunicação) - Programa de Pós-Graduação em Comunicação, Universidade Veracruzana, México, 2008.

TEPEDINO, G. Marchas e contramarchas da Constitucionalização do Direito Civil: A interpretação do Direito Privado à luz da Constituição da República. (Syn)thesis, Rio de Janeiro, v. 5, n. 1, p. 15-21, 2012. Disponível em: 〈https://goo.gl/b2pfu3〉. Acesso em: 20 jun. 2017. 
Krepsky / Para quem produzimos? Produção acadêmico-científica sobre o Direito e decisão judicial sob uma observação sistêmica

\section{APÊNDICE 1}

Quadro 1 - Categorização das unidades de sentido por frequência de temas das teses produzidas pelos programas de pós-graduação em Direito selecionados

\begin{tabular}{|c|c|c|c|c|c|}
\hline Unidades de sentido & FQ & Categoria inicial & $\begin{array}{c}\text { Categoria } \\
\text { intermediária }\end{array}$ & FQ & $\begin{array}{c}\text { Categoria } \\
\text { final }\end{array}$ \\
\hline $\begin{array}{ll}\text { Teóricos, teorias } & \mathrm{e} \\
\text { metodologias }\end{array}$ & 66 & \multirow{3}{*}{$\begin{array}{c}\text { Formas de compreensão } \\
\text { do Direito }\end{array}$} & \multirow{6}{*}{$\begin{array}{l}\text { Formas de } \\
\text { compreensão do } \\
\text { Direito }\end{array}$} & \multirow{6}{*}{106} & \\
\hline Direito e História & 30 & & & & \\
\hline Direito e Linguagem & 1 & & & & \\
\hline Bioética & 4 & \multirow{3}{*}{ Direito e Filosofia } & & & \\
\hline Sujeito e subjetividade & 3 & & & & \\
\hline Moral e valores & 2 & & & & \\
\hline Princípios & 24 & \multirow{5}{*}{ Direito e decisão } & \multirow{9}{*}{$\begin{array}{l}\text { Operacionalização do } \\
\text { Direito e acesso à } \\
\text { Justiça }\end{array}$} & \multirow{9}{*}{198} & \\
\hline $\begin{array}{lll}\text { Juízes, } & \text { jurisdição } & \mathrm{e} \\
\text { tribunais } & & \end{array}$ & 43 & & & & \\
\hline $\begin{array}{l}\text { Sistema Jurídico, } \\
\text { fundamento, efetividade e } \\
\text { aplicação do Direito }\end{array}$ & 10 & & & & \\
\hline $\begin{array}{l}\text { Decisão e argumentação } \\
\text { judicial }\end{array}$ & 38 & & & & \\
\hline $\begin{array}{lll}\text { Acesso à } & \text { Justiça } & \mathrm{e} \\
\text { judicialização }\end{array}$ & 6 & & & & \\
\hline Processo e Ações & 52 & \multirow{2}{*}{ Processo } & & & \\
\hline Processo Penal & 15 & & & & \\
\hline $\begin{array}{l}\text { Meios não adversariais de } \\
\text { solução de conflitos }\end{array}$ & 9 & \multirow[t]{2}{*}{ Conflito e solução } & & & $\stackrel{0}{=}$ \\
\hline Gestão de conflitos & 1 & & & & \\
\hline $\begin{array}{l}\text { Direitos Sociais, trabalho e } \\
\text { relações do trabalho }\end{array}$ & 51 & Relações do trabalho & \multirow{2}{*}{$\begin{array}{l}\text { Relações do trabalho e } \\
\text { empresa }\end{array}$} & \multirow[t]{2}{*}{85} & 绕魚 \\
\hline Relações da empresa & 34 & Relações da empresa & & & $\approx$ \\
\hline Contratos & 22 & \multirow{7}{*}{ Relações privadas } & \multirow{7}{*}{ Relações privadas } & \multirow{7}{*}{82} & 동 \\
\hline Posse e propriedade & 10 & & & & 。ै \\
\hline Consumo e comércio & 23 & & & & $\bar{z}$ \\
\hline Propriedade intelectual & 12 & & & & 空 \\
\hline $\begin{array}{l}\text { Responsabilidade } \\
\text { indenizações }\end{array}$ & 10 & & & & \\
\hline $\begin{array}{ll}\text { Capacidade } & \mathrm{e} \\
\text { personalidade } & \end{array}$ & 3 & & & & \\
\hline Negócio jurídico & 2 & & & & \\
\hline Direito e meio ambiente & 32 & \multirow[b]{2}{*}{ Direito e meio ambiente } & \multirow[b]{2}{*}{$\begin{array}{l}\text { Direito e meio } \\
\text { ambiente }\end{array}$} & \multirow[b]{2}{*}{36} & \\
\hline $\begin{array}{l}\text { Direito urbanístico e } \\
\text { território urbano }\end{array}$ & 4 & & & & \\
\hline $\begin{array}{l}\text { Democracia, cidadania e } \\
\text { participação }\end{array}$ & 23 & \multirow{3}{*}{ Relações de poder } & \multirow{8}{*}{ Direito e Política } & \multirow{8}{*}{246} & \\
\hline Direito, discurso e poder & 8 & & & & \\
\hline Liberdade de expressão & 4 & & & & \\
\hline $\begin{array}{l}\text { Violência, criminalidade e } \\
\text { segurança }\end{array}$ & 37 & Crime e sociedade & & & \\
\hline Estado e Constituição & 28 & \multirow{3}{*}{$\begin{array}{l}\text { Direito e Estado } \\
\text { Constitucional }\end{array}$} & & & \\
\hline Direito e Estado & 5 & & & & \\
\hline $\begin{array}{l}\text { Saúde, previdência e } \\
\text { seguridade }\end{array}$ & 27 & & & & \\
\hline $\begin{array}{l}\begin{array}{l}\text { Políticas públicas } \\
\text { governança }\end{array} \\
\end{array}$ & 15 & $\begin{array}{c}\text { Política e } \\
\text { Administração Pública }\end{array}$ & & & \\
\hline
\end{tabular}


Krepsky / Para quem produzimos? Produção acadêmico-científica sobre o Direito e decisão judicial sob uma observação sistêmica

\begin{tabular}{|c|c|c|c|c|c|}
\hline Unidades de sentido & FQ & Categoria inicial & $\begin{array}{c}\text { Categoria } \\
\text { intermediária }\end{array}$ & FQ & $\begin{array}{c}\text { Categoria } \\
\text { final }\end{array}$ \\
\hline $\begin{array}{l}\text { Controle e atuação da } \\
\text { Administração Pública }\end{array}$ & 28 & & & & \\
\hline $\begin{array}{l}\text { Tributação, orçamento, } \\
\text { finanças e planejamento }\end{array}$ & 39 & \multirow{3}{*}{$\begin{array}{c}\text { Tributação, orçamento e } \\
\text { economia }\end{array}$} & & & \\
\hline Direito e Economia & 20 & & & & \\
\hline $\begin{array}{ll}\text { Sistema } & \text { Financeiro } \\
\text { Nacional } & \\
\end{array}$ & 7 & & & & \\
\hline Poder Legislativo & 5 & Poder Legislativo & & & \\
\hline Ensino e Educação & 18 & \multirow{2}{*}{ Educação e profissão } & \multirow{2}{*}{ Educação e profissão } & & \\
\hline Profissão jurídica & 2 & & & 20 & \\
\hline $\begin{array}{ll}\begin{array}{l}\text { Direito, inovação } \\
\text { tecnologias }\end{array} & \mathrm{e} \\
\end{array}$ & 25 & Inovação e tecnologia & Inovação e tecnologia & 25 & \\
\hline $\begin{array}{l}\text { Culturas, coletividades e } \\
\text { movimentos sociais }\end{array}$ & 37 & \multirow{2}{*}{$\begin{array}{c}\text { Culturas, coletividades } \\
\text { e cooperação } \\
\text { comunitária }\end{array}$} & \multirow[t]{2}{*}{ Direito e culturas } & \multirow[b]{2}{*}{38} & \\
\hline Cooperação comunitária & 1 & & & & \\
\hline $\begin{array}{l}\text { Relações e c cooperação } \\
\text { internacionais }\end{array}$ & 29 & Relações Internacionais & $\begin{array}{c}\text { Relações } \\
\text { Internacionais }\end{array}$ & 29 & \\
\hline Direitos humanos & 19 & \multirow{2}{*}{$\begin{array}{c}\text { Direitos humanos e } \\
\text { fundamentais }\end{array}$} & \multirow{2}{*}{$\begin{array}{c}\text { Direitos humanos e } \\
\text { fundamentais }\end{array}$} & \multirow[b]{2}{*}{33} & \\
\hline Direitos fundamentais & 14 & & & & \\
\hline $\begin{array}{l}\text { Relações } \\
\text { famílias } \\
\text { sexual }\end{array}$ & 7 & \multirow[t]{2}{*}{$\begin{array}{l}\text { Relações familiares e } \\
\text { sucessões }\end{array}$} & \multirow[t]{2}{*}{$\begin{array}{l}\text { Relações familiares e } \\
\text { sucessões }\end{array}$} & \multirow[t]{2}{*}{9} & \\
\hline Sucessões & 2 & & & & \\
\hline TOTAL & & & & 907 & \\
\hline
\end{tabular}

Fonte: Elaboração própria.

Quadro 2 - Categorização das unidades de sentido por frequência de temas dos recursos julgados pelo Tribunal de Justiça de Santa Catarina

\begin{tabular}{|c|c|c|c|c|c|}
\hline $\begin{array}{l}\text { Unidades de } \\
\text { sentido }\end{array}$ & FQ & $\begin{array}{l}\text { Categoria } \\
\text { inicial }\end{array}$ & $\begin{array}{c}\text { Categoria } \\
\text { intermediária }\end{array}$ & FQ & $\begin{array}{l}\text { Categoria } \\
\text { final }\end{array}$ \\
\hline Acesso à Justiça & 132 & Acesso à Justiça & \multirow{3}{*}{$\begin{array}{c}\text { Operacionalização do } \\
\text { Direito e acesso à } \\
\text { Justiça }\end{array}$} & \multirow{3}{*}{3.908} & \multirow{16}{*}{4} \\
\hline Processo e Ações & 3.587 & Dor & & & \\
\hline Processo Penal & 189 & Processo & & & \\
\hline $\begin{array}{l}\text { Direitos } \\
\text { trabalho e relações do } \\
\text { trabalho }\end{array}$ & 4.303 & Relações do trabalho & $\begin{array}{l}\text { Relações do trabalho e } \\
\text { da empresa }\end{array}$ & 4.386 & \\
\hline Relações da empresa & 83 & Relações da empresa & & & \\
\hline Contratos & 19.162 & \multirow{8}{*}{ Relações privadas } & \multirow{8}{*}{ Relações privadas } & \multirow{8}{*}{53.588} & \\
\hline Posse e propriedade & 1.739 & & & & \\
\hline Consumo e comércio & 10.542 & & & & \\
\hline Propriedade intelectual & 287 & & & & \\
\hline $\begin{array}{ll}\text { Responsabilidade } & \mathrm{e} \\
\text { indenizações }\end{array}$ & 7.172 & & & & \\
\hline $\begin{array}{l}\text { Capacidade } \\
\text { personalidade }\end{array}$ & 54 & & & & \\
\hline Negócio Jurídico & 47 & & & & \\
\hline $\begin{array}{l}\text { Pagamentos e Títulos de } \\
\text { crédito }\end{array}$ & 14.585 & & & & \\
\hline Direito e meio ambiente & 44 & \multirow[b]{2}{*}{$\begin{array}{l}\text { Direito e meio } \\
\text { ambiente }\end{array}$} & \multirow{2}{*}{$\begin{array}{l}\text { Direito e meio } \\
\text { ambiente }\end{array}$} & \multirow[b]{2}{*}{57} & \\
\hline $\begin{array}{l}\text { Direito urbanístico e } \\
\text { território urbano }\end{array}$ & 13 & & & & \\
\hline Liberdade de expressão & 13 & Relações de poder & Direito e política & & \\
\hline
\end{tabular}


Krepsky / Para quem produzimos? Produção acadêmico-científica sobre o Direito e decisão judicial sob uma observação sistêmica

\begin{tabular}{|c|c|c|c|c|c|}
\hline $\begin{array}{l}\text { Unidades de } \\
\text { sentido }\end{array}$ & FQ & $\begin{array}{l}\text { Categoria } \\
\text { inicial }\end{array}$ & $\begin{array}{c}\text { Categoria } \\
\text { intermediária }\end{array}$ & FQ & $\begin{array}{c}\text { Categoria } \\
\text { final }\end{array}$ \\
\hline $\begin{array}{l}\text { Violência, criminalidade } \\
\text { e segurança }\end{array}$ & 16.569 & Crime e sociedade & & \multirow{5}{*}{37.469} & \\
\hline $\begin{array}{l}\text { Saúde, previdência, } \\
\text { seguridade e assistência }\end{array}$ & 10.777 & $\begin{array}{l}\text { Direito e Estado } \\
\text { Constitucional }\end{array}$ & & & \\
\hline $\begin{array}{l}\text { Controle e atuação da } \\
\text { Administração Pública }\end{array}$ & 1.962 & $\begin{array}{c}\text { Controle e } \\
\text { Administração } \\
\text { Pública }\end{array}$ & & & \\
\hline $\begin{array}{l}\text { Tributação, orçamento, } \\
\text { finanças e planejamento }\end{array}$ & 3.256 & \multirow{2}{*}{$\begin{array}{l}\text { Tributação e } \\
\text { Economia }\end{array}$} & & & \\
\hline $\begin{array}{ll}\text { Sistema } & \text { Financeiro } \\
\text { Nacional } & \\
\end{array}$ & 4.892 & & & & \\
\hline Ensino e educação & 307 & \multirow{2}{*}{ Educação e profissão } & \multirow{2}{*}{ Educação e profissão } & \multirow[t]{2}{*}{424} & \\
\hline Profissão jurídica & 117 & & & & \\
\hline $\begin{array}{l}\text { Relações parentais, das } \\
\text { famílias e diversidade } \\
\text { sexual }\end{array}$ & 2.431 & \multirow[t]{2}{*}{$\begin{array}{l}\text { Relações familiares e } \\
\text { sucessões }\end{array}$} & \multirow[t]{2}{*}{$\begin{array}{l}\text { Relações familiares e } \\
\text { sucessões }\end{array}$} & 2.543 & \\
\hline Sucessões & 112 & & & & \\
\hline TOTAL & \multicolumn{4}{|c|}{$\overline{102.3}$} & \\
\hline
\end{tabular}

Fonte: Elaboração própria.

Quadro 3 - Comparação temática (unidades de sentido) entre teses e recursos julgados

\begin{tabular}{|c|c|c|c|c|c|}
\hline $\mathbf{N}^{\mathbf{o}}$ & Auto-observação & $\%$ & $\begin{array}{c}\text { Observação acadêmico- } \\
\text { científica }\end{array}$ & $\%$ & $\neq(\%)$ \\
\hline $\mathbf{1}$ & Acesso à Justiça & 0,12 & Acesso à Justiça e judicialização & 0,66 & 450 \\
\hline $\mathbf{2}$ & Capacidade e personalidade & 0,05 & Capacidade e personalidade & 0,33 & 560 \\
\hline 3 & Consumo e comércio & 10,29 & Consumo e comércio & 2,54 & 305,11 \\
\hline 4 & Contratos & 18,71 & Contratos & 2,43 & 669,95 \\
\hline 5 & $\begin{array}{l}\text { Controle e atuação } \quad \text { da } \\
\text { Administração Pública }\end{array}$ & 1,91 & $\begin{array}{l}\text { Controle e atuação da Administração } \\
\text { Pública }\end{array}$ & 3,09 & 61,78 \\
\hline 6 & Direito e meio ambiente & 0,04 & Direito e meio ambiente & 3,31 & 8.175 \\
\hline 7 & $\begin{array}{l}\text { Direito urbanístico e território } \\
\text { urbano }\end{array}$ & 0,01 & Direito urbanístico e território urbano & 0,44 & 4.300 \\
\hline 8 & $\begin{array}{l}\text { Direitos sociais, trabalho e } \\
\text { relações do trabalho }\end{array}$ & 4,20 & $\begin{array}{l}\text { Direitos sociais, trabalho e relações do } \\
\text { trabalho }\end{array}$ & 5,64 & 34,28 \\
\hline 9 & Ensino e Educação & 0,29 & Ensino e Educação & 1,99 & 586,20 \\
\hline 10 & Liberdade de expressão & 0,01 & Liberdade de expressão & 0,44 & 4.300 \\
\hline 11 & Negócio Ju & 0,04 & Negócio jurídico & 0,22 & 450 \\
\hline 12 & Pagamentos e Títulos de crédito & 14,24 & - & - & \\
\hline 13 & Posse e propriedade & 1,69 & Posse e propriedade & 1,10 & 53,63 \\
\hline 14 & Processo e Ações & 3,50 & Processo e Ações & 5,75 & 64,28 \\
\hline 15 & Processo Penal & 0,18 & Processo Penal & 1,65 & 816,66 \\
\hline 16 & Profissão jurídica & 0,11 & Profissão jurídica & 0,22 & 100 \\
\hline 17 & Propi & 0,28 & intelectual & 1,32 & 371,42 \\
\hline 18 & Relações da empresa & 0,08 & Relações da empresa & 3,76 & 4.600 \\
\hline 19 & $\begin{array}{l}\text { Relações parentais, das famílias e } \\
\text { diversidade sexual }\end{array}$ & 2,37 & $\begin{array}{l}\text { Relações parentais, das famílias e } \\
\text { diversidade sexual }\end{array}$ & 0,77 & 207,79 \\
\hline 20 & Responsabilidade e indenizações & 7,00 & Responsabilidade e indenizações & 1,10 & 536,36 \\
\hline 21 & $\begin{array}{l}\text { Saúde, previdência, seguridade e } \\
\text { assistência }\end{array}$ & 10,52 & Saúde, previdência e seguridade & 2,98 & 253,02 \\
\hline 22 & Sistema Financeiro Nacional & 4,77 & Sistema Financeiro Nacional & 0,77 & 519,48 \\
\hline
\end{tabular}


Krepsky / Para quem produzimos? Produção acadêmico-científica sobre o Direito e decisão judicial sob uma observação sistêmica

\begin{tabular}{|c|c|c|c|c|c|}
\hline $\mathbf{N}^{\mathbf{0}}$ & Auto-observação & $\%$ & $\begin{array}{c}\text { Observação acadêmico- } \\
\text { científica }\end{array}$ & $\%$ & $\neq(\%)$ \\
\hline 23 & Sucessões & 0,10 & Sucessões & 0,22 & 120 \\
\hline 24 & $\begin{array}{l}\text { Tributação, orçamento, finanças e } \\
\text { planejamento }\end{array}$ & 3,18 & $\begin{array}{l}\text { Tributação, orçamento, finanças e } \\
\text { planejamento }\end{array}$ & 4,31 & 35,53 \\
\hline 25 & $\begin{array}{l}\text { Violência, criminalidade } \quad \mathrm{e} \\
\text { segurança }\end{array}$ & 16,18 & Violência, criminalidade e segurança & 4,09 & 295,59 \\
\hline 26 & - & - & Bioética & 0,44 & \\
\hline 27 & - & - & Cooperação comunitária & 0,11 & \\
\hline 28 & - & - & $\begin{array}{l}\text { Culturas, coletividades e movimentos } \\
\text { sociais }\end{array}$ & 4,09 & \\
\hline 29 & - & - & Decisão e argumentação judicial & 4,20 & \\
\hline 30 & - & - & Democracia, cidadania e participação & 2,54 & \\
\hline 31 & - & - & Direito e Economia & 2,21 & \\
\hline 32 & - & - & Direito e Estado & 0,55 & \\
\hline 33 & - & - & Direito e História & 3,31 & \\
\hline 34 & - & - & Direito e Linguagem & 0,11 & \\
\hline 35 & - & - & Direito, discurso e poder & 0,88 & \\
\hline 36 & - & - & Direito, inovação e tecnologias & 2,76 & \\
\hline 37 & - & - & Direitos fundamentais & 1,54 & \\
\hline 38 & - & - & Direitos humanos & 2,10 & \\
\hline 39 & - & - & Estado e Constituição & 3,09 & \\
\hline 40 & - & - & Gestão de conflitos & 0,11 & \\
\hline 41 & - & - & Juízes, jurisdição e tribunais & 4,75 & \\
\hline 42 & - & - & $\begin{array}{l}\text { Meios não adversariais de solução de } \\
\text { conflitos }\end{array}$ & 0,99 & \\
\hline 43 & - & - & Moral e valores & 0,22 & \\
\hline 44 & - & - & Poder Legislativo & 0,55 & \\
\hline 45 & - & - & Políticas públicas e governança & 1,65 & \\
\hline 46 & - & - & Princípios & 2,65 & \\
\hline 47 & - & - & Relações e cooperação internacionais & 3,20 & \\
\hline 48 & - & - & $\begin{array}{l}\text { Sistema jurídico, fundamento, } \\
\text { efetividade e aplicação do Direito }\end{array}$ & 1,10 & \\
\hline 49 & - & - & Sujeito e subjetividade & 0,33 & \\
\hline 50 & - & - & Teóricos, teorias e metodologias & 7,30 & \\
\hline
\end{tabular}

Fonte: Elaboração própria. 